\title{
Effect of bio-finishes on designer's naturally coloured cotton khadi stripe fabrics
}

\author{
Dr. Namrata M. ${ }^{1}$ and Dr. Shailaja D. Naik ${ }^{2}$ \\ ${ }^{1}$ (Assistant Professor in Home Science, Govt. First Grade College for women, Jamakhandi, Tq.: Jamakhandi, \\ Dist.: Bagalkot, State: Karnataka, India) \\ ${ }^{2}$ (Professor in Department of Textile and Apparel Designing, College of Rural Home Science, University of \\ Agricultural Sciences, Dharwad-5, Karnataka, India)
}

\begin{abstract}
The present study involves the eco-friendly naturally coloured cotton DDCC-1 and white cotton yarns which were used to produce pin and medium stripe khadi fabrics and given special bio-finishes viz., enzymatic de-sizing, bio-polishing and silicon softener finish and further tested to know their impact on different structural, performance and durable properties. Multiple linear regressions were used to analyse their influence on one another. It was found that on special finishing, both WC and DDCC-1 yarns became finer and slight increase in cloth count; considerable reduction in bending length; improvement in crease recovery angle and drapability of both the stripe fabrics was observed. Whereas, tensile strength and elongation were reduced; and no considerable change was observed in abrasion and pilling.
\end{abstract}

Keywords: DDCC-1, Designer's fabrics, enzyme finish, medium stripe, naturally coloured cotton, physical properties, pin stripe, softener wash, and special finish

\section{Introduction}

Today's eco-friendly consumers have several choices while picking cotton clothing. But, these cottons are grown with harmful chemicals that pollute the environment. Due to pollution, consumer awareness and about eco-friendly concept revitization of old techniques, they are opening their minds towards organically grown cotton, naturally coloured cotton and recycled cotton products. These may cost a little extra, but by supporting eco-friendly cotton industry, as consumers were protect the future planet too.

In 1982, an entomologist Sally Fox reintroduced naturally colored cotton which eliminated the need for dyeing. Cottons of different colors have always existed in nature. Like our eyes or hair, cotton is genetically encoded with colors ranging from brown to tan. Native peoples have used these wild cottons for weaving and hand spinning for centuries. Most of the consumers know that naturally coloured cotton due to dyeing which is not so. Naturally Coloured Cotton is not a product of any recent genetic engineering or bio-technology. Several lint colours-brown, black, mahagony red, red, khaki, pink, blue, green, creamy white and ofcourse white belonged to four species of genus Gossypium viz., arboreum, herbaceum, hirsutum and barbadense. Evidence for its cultivation in India is obtained from the remains of the Indus Valley Civilization. It is also noted in an ancient Indian book Vriksha Ayurveda that they were being cultivated by the tribal people living in Narmada basin in Central India. The coloured cotton species Cocanadas 1 and 2 were commercially cultivated in Andhra Pradesh upto the middle of the $20^{\text {th }}$ century and were exported to Japan. Similarly, cotton of black, brown, khaki and creamy white lint were grown in Assam. Kumta in Karnataka was the home for G.herbaceum with dull white lint (Murthy, 2001).

With the increasingly important requirement for textile manufacturers to reduce pollution in textile production, the use of enzymes in the chemical processing of fibres and textiles is rapidly gaining wider recognition because of their non-toxic and eco-friendly characteristics. They can be safely used in a wide selection of textile processes such as de-sizing, scouring, bleaching, dyeing and finishing, where the alternatives are very harsh chemicals whose disposal into the environment causes many problems.

The environment in textile industry is becoming an increasingly competitive. Differentiating products by quality is particularly important. Testing can be performed both to improve product quality and achieve compliance to international, regional or retailer specific standards. Testing of fabrics is a valuable resource for designers, technologists, quality inspectors and testing institutes in the textile industry. It is also relevant for academics and students within the textile field.

Textile or fabric testing is extremely important in determining the quality and performance of products, and also establishing regulatory compliance with the various stringent standards set by various government bodies. Textiles directly get into touch with our bodies, and so testing for such chemical compounds which affect the health (specifically skin) of an individual is crucial, and this becomes even more important for infants and children whose skins are far more sensitive than that of adults. 
There are various testing parameters of textiles which have been devised to determine the performance and safety of the products. The importance of testing of textiles is for the following reasons:

- Ensuring quality conformance of raw materials

- Checking quality, in terms of performance and safety, of final products

- Improving manufacturing process in a cost-effective manner

- Ensuring customer satisfaction

In the present study, efforts were made to test the eco-friendly naturally coloured cotton stripe khadi fabrics by giving special bio-finishes. The study aimed at the following objective:

- To study the impact of enzyme and silicon softener finish on pin and medium stripe khadi fabric

- To enumerate the influence of structural and performance properties on drapability and tensile strength

\subsection{Procurement of Raw materials}

\section{Research Methodolgy}

Raw materials are the basic components required to manufacture a final product. In the present study, cotton fibre is the main raw material to produce khadi fabrics. The DDCC-1 (Dharwad Desi Colour Cotton-1) naturally coloured cotton (Gossypium arboreum) released by University of Agricultural Sciences, Dharwad and Jayadhar white cotton variety lint were procured from Khadi Nekar Sahakari Sangh Niyamita, Uppina Betageri, Dharwad.

\subsection{Loom and fabric details}

Both the khadi fabrics, DDCC-1 and white cotton (WC) were used to produce two stripe fabrics viz., pin (warp X weft : 2 DDCC-1, 2WC X DDCC-1) (Plate 1) and medium (warp X weft : 8 DDCC-1, 4WC X DDCC-1) (Plate 2) stripes which woven on pit loom with reed count 40 and denting order of 2 threads / dent. The width of the fabric was $28^{\prime \prime}(70 \mathrm{~cm})$ woven by using reed width of $30^{\prime \prime}$.

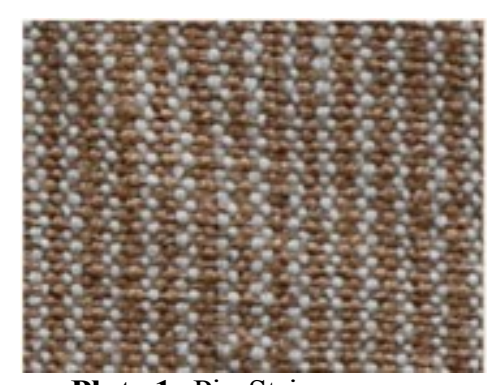

Plate 1: Pin Stripe

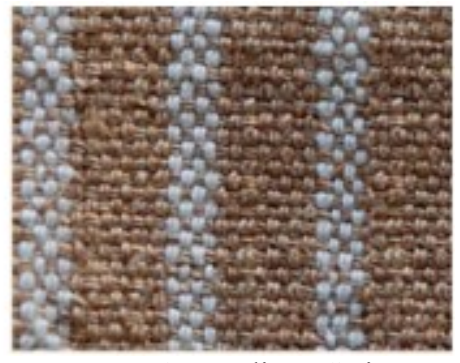

Plate 2: Medium Stripe

2.3 Eco-friendly bio - finishes to naturally coloured cotton stripe khadi fabrics

In this study, the exclusively designed khadi fabrics were subjected for enzymatic desizing also called as bio-desizing followed by biopolishing and finally silicon softener finish at Bio-care Garment Processors Pvt. Ltd., Bangalore.

The following standard method as mentioned in Table 1 is viable commercially. After final finishing the treated fabrics were then run in hydro extractor machine for 15 minutes to remove excess finishing solution and tumble dried below $120^{\circ} \mathrm{C}$ (Plate 3).

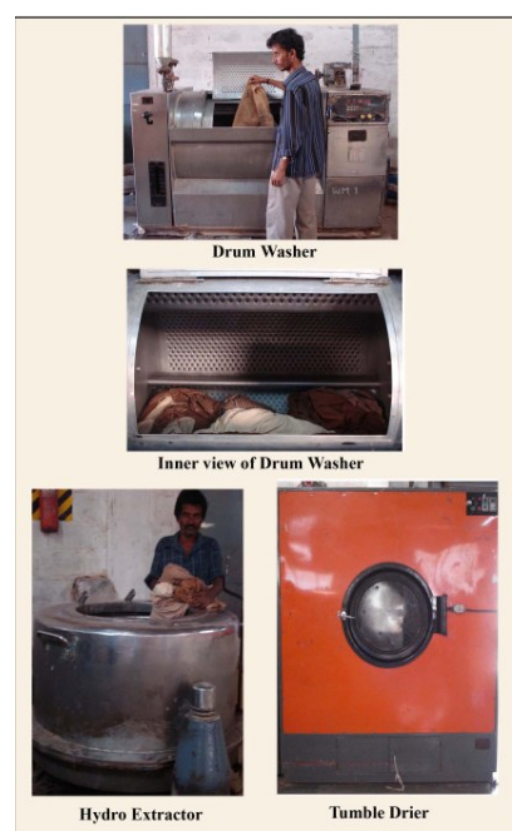

Plate 3 : Finishing Machineries 
Table 1. Recipe of special finishes

\begin{tabular}{|c|l|l|l|l|}
\hline Sl. No. & Recipe & Bio-desizing & Bio-polishing & Silicon Softener \\
\hline 1 & MLR & $1: 10$ & $1: 10$ & $1: 10$ \\
\hline 2 & Treatment time & $20 \mathrm{~min}$ & $45 \mathrm{~min}$ & $20 \mathrm{~min}$ \\
\hline 3 & Treatment temperature & $40^{\circ} \mathrm{C}$ & $50^{\circ} \mathrm{C}$ & - \\
\hline 4 & $\mathrm{pH}$ & - & $4.5-5$ & $4.5-5$ \\
\hline 5 & Acid & - & Acetic acid & Acetic acid \\
\hline 6 & Clariant desize & $30 \mathrm{ml} / \mathrm{kg}$ of fabric & & - \\
\hline 7 & & & & - \\
\hline 8 & Refnol lubricant & $25 \mathrm{ml} / \mathrm{kg}$ of fabric & $25 \mathrm{ml} / \mathrm{kg}$ of fabric & - \\
\hline 9 & Resil Silicon & - & $30 \mathrm{ml} / \mathrm{kg}$ of fabric & - \\
\hline 9 & Pidilite Softener & - & - & $25 \mathrm{ml} / \mathrm{kg}$ of fabric \\
\hline 10 & Finishing machine & Drum washer & Drum washer & $50 \mathrm{ml} / \mathrm{kg}$ of fabric \\
\hline 11 & Method incorporated & Hot method & Hot method & Cold method \\
\hline
\end{tabular}

\subsection{Quality assessment of DDCC-1 and white cotton}

Quality assessment plays a major role in determining the durability, hand - feel and texture of the fabric. After finishing, there will be drastic improvement in the physical parameters of the fabric. Hence, physical testing was carried out in Testing Laboratory, Department of Textile and Apparel Designing, College of Rural Home Science, University of Agricultural Sciences, Dharwad.

\subsection{Statistical Analysis}

To know the individual effect of all the independent variables of the physical parameters on the corresponding dependent variable, multiple linear regressions was carried out using the formula,

$$
\begin{aligned}
& \begin{aligned}
\text { Where } y & =\mathrm{a}_{0}+\mathrm{a}_{1} \mathrm{x}_{1}+\mathrm{a}_{2} \mathrm{x}_{2}+\ldots \ldots \ldots \ldots \\
& =\text { Dependent variable }
\end{aligned} \\
& \begin{array}{ll}
\mathrm{x}_{1} \cdot \mathrm{x}_{2} \ldots \ldots \ldots \ldots \ldots \ldots \mathrm{x}_{\mathrm{n}} & =\text { Independent variables } \\
\mathrm{E} & =\text { Random variable showing error } \\
\mathrm{X}_{\mathrm{n}} & =\text { Independent dummy variable }
\end{array} \\
& \text { (Value }=0 \text { for before treatment; } \\
& \text { Value }=1 \text { for after treatment) }
\end{aligned}
$$

Co-efficient of determination $\left(\mathrm{R}^{2}\right)$ was calculated to know the effect of independent variables on the corresponding dependent variable using the formula,

$\mathrm{R}^{2}=$ Sum of squares due to multiple regression

\subsection{Effect of enzyme and softener finish on structural properties \\ III. Results And Discussio}

\begin{tabular}{|c|c|c|c|c|c|c|c|c|c|c|}
\hline \multirow{2}{*}{$\begin{array}{l}\text { Sl. } \\
\text { No. }\end{array}$} & \multirow{2}{*}{$\begin{array}{c}\text { Designer's } \\
\text { fabrics }\end{array}$} & \multirow{2}{*}{ Treatment } & \multicolumn{2}{|c|}{ Yarn count $(\mathrm{Ne})$} & \multicolumn{2}{|c|}{$\begin{array}{l}\text { Cloth Count } \\
\text { (Numerical } \\
\text { expression) }\end{array}$} & \multirow{2}{*}{$\begin{array}{l}\text { Cloth } \\
\text { Thicknes } \\
\text { s (mm) }\end{array}$} & \multicolumn{3}{|c|}{ Cloth Weight (GSM) } \\
\hline & & & Warp & Weft & Warp & Weft & & $\begin{array}{l}\text { Cloth } \\
\text { Weight } \\
\text { (GSM) }\end{array}$ & $\begin{array}{c}\text { Warp } \\
\text { percentage }\end{array}$ & $\begin{array}{c}\text { Weft } \\
\text { percentage }\end{array}$ \\
\hline \multirow{2}{*}{1} & \multirow{2}{*}{ Pin stripe } & Control & $\begin{array}{c}276 \mathrm{~s}, 27 \\
7 \mathrm{~s}\end{array}$ & $2 / 85$ & 42 & 27 & 0.74 & 230.48 & 58.94 & 41.06 \\
\hline & & $\begin{array}{l}\text { Enzyme + } \\
\text { softener finish }\end{array}$ & $\begin{array}{c}2 / 85,27 \\
95\end{array}$ & $2 / 85$ & $\begin{array}{c}44 \\
(+04.76)\end{array}$ & $\begin{array}{c}30 \\
(+11.11)\end{array}$ & $\begin{array}{c}0.70 \\
(-05.41)\end{array}$ & $\begin{array}{l}214.08 \\
(-07.12)\end{array}$ & $\begin{array}{c}58.12 \\
(-00.82)\end{array}$ & $\begin{array}{c}41.88 \\
(+00.82)\end{array}$ \\
\hline \multirow[b]{2}{*}{2} & \multirow{2}{*}{$\begin{array}{l}\text { Medium } \\
\text { stripe }\end{array}$} & Control & $\begin{array}{c}2 / 65,27 \\
75\end{array}$ & $2 / 8 s$ & 42 & 26 & 0.75 & 234.48 & 66.38 & 33.62 \\
\hline & & $\begin{array}{l}\text { Enzyme + } \\
\text { softener finish }\end{array}$ & $\begin{array}{c}2 / 8 s, 2 / \\
9 s\end{array}$ & $2 / 85$ & $\begin{array}{c}44 \\
(+04.76)\end{array}$ & $\begin{array}{c}30 \\
(+15.38)\end{array}$ & $\begin{array}{c}0.71 \\
(-05.33)\end{array}$ & $\begin{array}{l}218.96 \\
(-06.62)\end{array}$ & $\begin{array}{c}60.28 \\
(-06.10)\end{array}$ & $\begin{array}{c}39.72 \\
(+06.10)\end{array}$ \\
\hline
\end{tabular}

The yarn count, cloth count, thickness and GSM are the basic yet foundation parameters under the umbrella of structural properties as depicted in Table 2.

Table 2. Effect of enzyme and softener finish on structural properties

Note: Figures in parenthesis indicate percentage change over control

The weft yarn for both pin and medium stripe samples is DDCC-1 only whereas the warp consists of DDCC-1 and WC in different proportions. Hence the yarn count appears to be same for both the stripe samples. Table 2 clearly depicts that the weft way yarn count has remained constant $(2 / 8 \mathrm{~s})$ even after treatment whereas the warp way count $(2 / 8 \mathrm{~s}, 2 / 9 \mathrm{~s})$ was higher after treatment than the control samples which was found to be $2 /$ $6 \mathrm{~s}, 2 / 7 \mathrm{~s}$. This may be because the naturally coloured cotton and white cotton yarns were sized before warping 
and some percent of it was desized during finishing. Meanwhile, there was slight variation in warp and weft counts which may be attributed to unevenness and coarseness of hand spun yarns.

It is observed from Table 2 that in both the stripe fabrics, the warp density is relatively greater than the weft. After treatment, the fabrics have become compact and this compactness is more in weft than warp. The increase in warp density of both stripe types was same (04.76\%) but the increase in weft density was slightly higher with medium stripe (15.38\%) than the pin stripe (11.11\%). This may be due to consolidation of yarns in both directions on application of special finishes i.e. enzyme and softener wash; in turn resulting into increase in the yarn density and compactness of weave. Further no difference was observed in warp density of both the stripe samples which may be because of weave calculation that remained same for both the fabrics; however slight difference in weft density was observed which may be attributed to a process viz., beating up in hand weaving that varied among individual weaver. The results are supported by Suman and Khambra (2003), who stated that cellulose enzymatic treatment lead to increase in cloth count of both cent per cent cotton denim (light weight and heavy weight denim) and blended cotton denim (synthetic denim).

It is evident from Table 2 that irrespective of type of stripe fabric, the cloth thickness has reduced after giving enzyme and softener wash. Among the striped samples, the sample with medium stripes $(00.75 \mathrm{~mm})$ appeared to be slightly thicker than pin stripe $(00.74 \mathrm{~mm})$ before treatment. And after the treatment there was slight increase in the value of pin stripe (05.41\%) when compared to medium stripe $(05.33 \%)$. The test samples have become thinner on subsequent wet processing which may be mainly because of the physical changes evolved during enzyme and softener finishes. Nevertheless, the cloth thickness of pin stripe was comparatively lesser than medium stripe fabric may be due to fabric composition where DDCC-1 is more than 50 percent among pin stripe and more than 75 percent in medium stripe fabric. DDCC-1 yarn is relatively coarser than WC. These results are on par with the study conducted by Raje et al. (2001) where that the cloth thickness reduced on treating cotton fabric with commercial endogluconase cellulose enzyme finish and silicone softener finish.

It was noticed from Table 2 that a decrease in the GSM (07.12 \%) of pin stripe sample was observed with an equal amount of decrease and increase in warp and weft percentages $(0.82 \%)$. Similarly there was a decrease in the value of GSM $(06.62 \%)$ with decrease in warp percentages $(06.10 \%)$ and increase in weft percentages $(06.10 \%)$ of medium stripe fabric, on treating with enzyme + softener finish. This may be because of removal of greater percent of surface fibres or fuzz present on the fabric, along with sizing material during mechanical agitation involved while giving special finish. The GSM of pin stripe was relatively lower compared to medium stripe, this may be attributed to fabric composition where percentage of DDCC-1 is more than 50 percent among pin stripe and is more than 75 percent in medium stripe fabric. Greater the percentage of DDCC1 higher is the GSM because of DDCC-1 yarn being relatively coarser than WC, invariably added to the GSM.

\subsection{Effect of enzyme and softener finish on performance properties}

Every fabric manufactured has definite end use, thus has all intrinsic qualities or characteristics to perform better as per the specification. There are several parameters of a cloth that determine its performance viz., bending path, crease recovery and drape coefficient as depicted in Table 3.

Table 3. Effect of enzyme and softener finish on performance properties

\begin{tabular}{|c|c|c|c|c|c|c|c|c|c|}
\hline \multirow[b]{2}{*}{$\begin{array}{l}\text { Sl. } \\
\text { No. }\end{array}$} & \multirow{2}{*}{$\begin{array}{c}\text { Designer' } \\
\text { s fabrics }\end{array}$} & \multirow[b]{2}{*}{ Treatment } & \multicolumn{3}{|c|}{ Cloth Crease Recovery (Degree) } & \multicolumn{2}{|c|}{ Cloth Stiffness $(\mathrm{cm})$} & \multicolumn{2}{|c|}{ Cloth Drapability (\%) } \\
\hline & & & Warp & Weft & $\begin{array}{l}\text { Cloth crease } \\
\text { recovery }\end{array}$ & Warp & Weft & $\begin{array}{l}\text { No. of } \\
\text { nodes }\end{array}$ & $\begin{array}{c}\text { Drape } \\
\text { Coefficient }\end{array}$ \\
\hline \multirow[b]{2}{*}{1} & \multirow[b]{2}{*}{ Pin stripe } & Control & 83 & 92 & 87.36 & 2.84 & 2.26 & 3 & 113.24 \\
\hline & & $\begin{array}{l}\text { Enzyme + } \\
\text { softener finish }\end{array}$ & $\begin{array}{c}78 \\
(.06 .02)\end{array}$ & $\begin{array}{c}81 \\
(-11.96)\end{array}$ & $\begin{array}{c}79.47 \\
(.09 .03)\end{array}$ & $\begin{array}{c}1.64 \\
(-42.25)\end{array}$ & $\begin{array}{c}1.59 \\
(-29.65)\end{array}$ & 5 & $\begin{array}{c}62.47 \\
(-44.83)\end{array}$ \\
\hline \multirow{2}{*}{2} & \multirow{2}{*}{$\begin{array}{l}\text { Medium } \\
\text { stripe }\end{array}$} & Control & 89 & 97 & 92.89 & 3.13 & 2.31 & 2 & 132.27 \\
\hline & & $\begin{array}{l}\text { Enzyme + } \\
\text { softener finish }\end{array}$ & $\begin{array}{c}81 \\
(.08 .99)\end{array}$ & $\begin{array}{c}85 \\
(-12.37)\end{array}$ & $\begin{array}{c}82.98 \\
(-10.67)\end{array}$ & $\begin{array}{c}1.50 \\
(-52.08)\end{array}$ & $\begin{array}{c}1.52 \\
(-34.20) \\
\end{array}$ & 5 & $\begin{array}{c}64.31 \\
(-51.38)\end{array}$ \\
\hline
\end{tabular}

Note: Figures in parenthesis indicate percentage change over control

It is evident that the weft crease recovery of both the test samples was greater than the corresponding warpway at control and after wet treatment. Nevertheless, both the test fabrics have shown an improvement in crease recovery after softener finish. Among the stripes, pin stripe $(79.47 \%)$ exhibited better cloth crease recovery after the wet treatment than medium stripe (82.98\%). This may be because of the effect of finishes (enzyme and softener) that imparted softness by hydrolyzing and removing the surface fibres thus reducing the stiffness due to deposition of a thin film on the surface which is exceptionally soft. These results are supported by the values of reduction in bending length on finishing. Greater the percentage of DDCC-1 higher is the crease recovery angle because of DDCC-1 yarn being relatively coarser than WC, invariably added to the crease recovery. 
Both the test samples showed longer bending path in the warpway compared to weftway. It is noticed that both warpway $(03.13 \mathrm{~cm})$ and weftway $(02.31 \mathrm{~cm})$ bending length of medium stripe was relatively higher than that of corresponding warpway $(02.84 \mathrm{~cm})$ and weftway $(02.26 \mathrm{~cm})$ of pin stripe. A trend of similar results with the percent change over control was observed in the treated fabrics, when compared to untreated samples. Sizing warp sheet during pre loom process did stiffen the ends, which in turn helped to maintain the warp tension, parallel alignment to the ground as well to with stand the abrasion during primary motion. Meanwhile size did contribute to the cloth stiffness. These results are in line with the study conducted by Suman and Khambra (2003), who observed that the bending length of denim fabrics decreased after enzyme treatment.

It was observed from Table 3 that among the stripes, the medium stripe sample showed relatively poor drapability ( 2 nodes and $132.27 \%$ ) than pin stripe ( 3 nodes and $113.24 \%$ ). However, relatively a poor drapability was exhibited by medium stripe $(64.31 \%)$ than pin stripe $(62.47 \%)$ but both draped with 5 nodes. Medium stripe sample showed poor drape which may be because of presence of greater number of DDCC-1 yarns in the warp and weft directions when compared to pin stripe even after treating the samples with special finishes. The results are on par with study conducted by Kurlageri (2009) where enzymatic finish improved the drapability of organic handloom cotton fabric sample to some extent, which is further improved by softener treatment.

\subsection{Influence of cloth count, cloth weight, cloth thickness, cloth crease recovery and cloth stiffness on cloth drapability}

A multiple linear regression analysis was carried out to study the influence of different cloth parameters like cloth count, cloth weight, cloth thickness, cloth crease recovery and cloth stiffness on drapability. An attempt was also made to study the influence of these factors on cloth drapability before and after the treatment by introducing a dummy independent variable. (Value 0 for before and value 1 for after treatment).

The cloth parameters like cloth count, cloth crease recovery and cloth stiffness have two dimensions viz., warp and weft. The two dimensions are likely to influence the drapability. Hence they were added to get their combined effect on drapability. The results of the multiple linear regression analysis are presented in the Table 4.

Table 4. Influence of cloth count, cloth weight, cloth thickness, cloth crease recovery and cloth stiffness on cloth drapability

\begin{tabular}{|c|c|c|c|c|c|c|c|c|c|c|}
\hline $\begin{array}{l}\text { Sl. } \\
\text { No. }\end{array}$ & $\begin{array}{c}\text { Designer's } \\
\text { fabrics }\end{array}$ & Intercept & $\begin{array}{c}\mathrm{Xl} \\
\text { Cloth } \\
\text { count }\end{array}$ & $\begin{array}{c}\mathrm{X} 2 \\
\text { Cloth } \\
\text { weight }\end{array}$ & $\begin{array}{c}\mathrm{X} 3 \\
\text { Cloth } \\
\text { thickness }\end{array}$ & $\begin{array}{c}\mathrm{X} 4 \\
\text { Cloth } \\
\text { crease } \\
\text { recovery }\end{array}$ & $\begin{array}{c}\text { X5 } \\
\text { Cloth } \\
\text { stiffness }\end{array}$ & $\begin{array}{c}\text { X6 } \\
\text { Dummry } \\
\text { variable }\end{array}$ & $\mathrm{R}^{2}$ & F-value \\
\hline 1 & Pin Stripe & $\begin{array}{l}95.56^{\circ} \\
(16.71)\end{array}$ & $\begin{array}{l}0.01^{N \alpha} \\
(0.11)\end{array}$ & $\begin{array}{l}-0.08^{\mathrm{Na}} \\
(0.05)\end{array}$ & $\begin{array}{c}-9.02^{\mathrm{Na}} \\
(8.86)\end{array}$ & $\begin{array}{l}0.24^{*} \\
(0.05)\end{array}$ & $\begin{array}{l}0.73^{\mathrm{No}} \\
(1.59)\end{array}$ & $\begin{array}{c}-55.09^{*} \\
(3.45)\end{array}$ & $0.998^{\circ-}$ & 1581.38 \\
\hline 2 & Medium Stripe & $\begin{array}{c}-36.82^{\mathrm{Ns}} \\
(61.00)\end{array}$ & $\begin{array}{l}0.49^{\text {No }} \\
(0.32)\end{array}$ & $\begin{array}{l}0.39^{*} \\
(0.12)\end{array}$ & $\begin{array}{l}-2.82^{\mathrm{NS}} \\
(16.03)\end{array}$ & $\begin{array}{l}0.33^{*} \\
(0.11)\end{array}$ & $\begin{array}{c}-1.62^{\mathrm{Ns}} \\
(2.54)\end{array}$ & $\begin{array}{c}-74.79^{*} \\
(6.60)\end{array}$ & $0.994^{*}$ & 653.78 \\
\hline
\end{tabular}

Note: *Significant at 5 per cent level, ** Significant at 1 per cent level, NS- Non-significant

Figures in parenthesis indicate standard error

In case of pin stripe fabric, the regression model explained 99.8 per cent of variation in the drapability due to variation in cloth parameters. The regression model was significant at 1 per cent. Only count crease recovery was found to significantly and positively condition the drapability. One degree increase in cloth crease recovery would increase the drape co-efficient by 0.24 per cent. Cloth weight and cloth thickness were having negative influence while cloth count and cloth stiffness were having positive influence. However, these influences were statistically not significant. The drape co-efficient was found to decrease by 55.09 per cent from 99.56 per cent because of the treatment.

About 99 per cent of variation in drapability was found to explain by the variation in independent variables in the case of medium stripe fabrics. The F-value was very high indicating that the regression model was a good fit. The cloth weight was found to positively and significantly condition the drape co-efficient. An increase of 1 GSM of cloth weight will increase 0.39 per cent drape co-efficient. Similarly, 1 degree increase in cloth crease recovery would increase the drape co-efficient by 0.33 per cent. Cloth thickness and cloth stiffness were found to influence drape co-efficient negatively. While cloth count produced a positive influence on drape co-efficient. However, these influences were statistically not established. The drape co-efficient came down by 74.79 per cent due to the treatment. 


\subsection{Effect of enzyme and softener finish on durable properties}

The laboratory approach to assess the durability of the test samples in this study are abrasion resistance, pilling, tensile strength and its corresponding elongation as shown in Table 5.

Table 5. Effect of enzyme and softener finish on durable properties

\begin{tabular}{|c|c|c|c|c|c|c|c|c|}
\hline \multirow{2}{*}{$\begin{array}{l}\text { Sl. } \\
\text { No. }\end{array}$} & \multirow{2}{*}{$\begin{array}{l}\text { Designer's } \\
\text { fabrics }\end{array}$} & \multirow{2}{*}{ Treatment } & \multicolumn{2}{|c|}{$\begin{array}{c}\text { Cloth Tensile Strength } \\
\text { (kgf) }\end{array}$} & \multicolumn{2}{|c|}{ Cloth Elongation (\%) } & \multirow{2}{*}{$\begin{array}{c}\text { Cloth } \\
\text { abrasion } \\
\text { (cycles) }\end{array}$} & \multirow{2}{*}{$\begin{array}{c}\text { Cloth } \\
\text { pilling } \\
\text { (ratings) }\end{array}$} \\
\hline & & & Warp & Weft & Warp & Weft & & \\
\hline 1 & Pin stripe & $\begin{array}{l}\text { Enzyme }+ \\
\text { softener finish }\end{array}$ & $\begin{array}{c}24.03 \\
(-44.25) \\
\end{array}$ & $\begin{array}{c}17.30 \\
(-35.54) \\
\end{array}$ & $\begin{array}{c}11.31 \\
(-20.24) \\
\end{array}$ & $\begin{array}{c}7.49 \\
(-13.11) \\
\end{array}$ & $\begin{array}{l}\text { Above } \\
10,000\end{array}$ & 1 \\
\hline \multirow{2}{*}{2} & \multirow{2}{*}{ Medium stripe } & Control & 45.36 & 31.20 & 13.40 & 7.12 & $\begin{array}{l}\text { Above } \\
10,000\end{array}$ & 1 \\
\hline & & $\begin{array}{l}\text { Enzyme }+ \\
\text { softener finish }\end{array}$ & $\begin{array}{c}26.50 \\
(-41.58) \\
\end{array}$ & $\begin{array}{c}21.37 \\
(-31.51) \\
\end{array}$ & $\begin{array}{c}8.10 \\
(-39.55) \\
\end{array}$ & $\begin{array}{c}6.42 \\
(-09.83) \\
\end{array}$ & $\begin{array}{l}\text { Above } \\
10,000\end{array}$ & 1 \\
\hline
\end{tabular}

Note: Figures in parenthesis indicate percentage change over control

The warpway tensile strength of both the stripe samples is greater than its corresponding weftway strength even after softener finish. However, the softener finish has reduced the tensile strength of the samples both warp and weftways. Of the two stripe samples, maximum tensile strength in warp ( $26.50 \mathrm{kgf})$ and weftway (21.37 kgf) was observed with medium stripe than pin stripe (warpway, $24.03 \mathrm{kgf}$ and weftway, $17.30 \mathrm{kgf}$ ). This may be because the tensile forces readily displaced the cellulose molecules in the amorphous region of untreated sample where the fibres readily stretched to absorb a considerable amount of force applied. Finer yarns resulted into finer cloth count and the latter has negatively influenced the cloth weight as well as cloth thickness; finally showed a negative trend in tensile properties of special finished designer's khadi fabrics. These results are in line with the study conducted by Kurlageri (2009) where the enzyme and softener treated samples showed decrease in tensile strength.

Table 5 depicts that the warpway elongation was higher than weftway at control; the elongation percentage gradually decreased both in warp and weftways after treating the samples with special finishes. Pin stripe sample showed higher elongation percentages in warp $(11.31 \%)$ and weft $(7.49 \%)$ direction compared to warp $(8.10 \%)$ and weft $(6.42 \%)$ elongation percentages of medium stripe. The fall in the elongation percentage value may be because of increase in yarn fineness, decrease in cloth thickness due to dehairing, softness, pliability of the fabric.

It is indicated from Table 5 that medium stripe sample before and after treatment are able to withstand more than 10,000 abrasion cycles except for pin stripe which was 9,777 abrasion cycles before treatment. There is no difference in the abrasion resistance between the control and treated fabrics except in pin stripe where there is negligible increase in abrasion resistance. The structural properties influencing the cloth abrasion resistance to a greater extent are fibre content, yarn count and thickness and to some extent, the fabric sett and the starch held mechanically on the cloth surface.

Table 5 clearly indicates that there are no pills for the entire fabric samples showing special finishes improved pilling resistance. It may also be noted here that there is not much difference in abrasion resistance between control and treated samples; so also the pilling values.

3.5 Influence of cloth count, cloth weight and cloth thickness on tensile strength

A multiple linear regression analysis was carried out to study the influence of different cloth parameters like cloth count, cloth weight and cloth thickness on cloth tensile strength. An attempt was also made to study the influence of these factors on cloth tensile strength before and after the treatment by introducing a dummy independent variable. (Value 0 for before and value 1 for after treatment).

The cloth parameter like cloth count has two dimensions viz., warp and weft. The two dimensions are likely to influence the cloth tensile strength. Hence they were added to get their combined effect on tensile strength. The results of the multiple linear regression analysis are presented in the Table 6 .

Table 6. Influence of cloth count, cloth weight, and cloth thickness on cloth tensile strength

\begin{tabular}{|c|l|c|c|c|c|c|c|c|}
\hline $\begin{array}{c}\text { Sl. } \\
\text { No. }\end{array}$ & $\begin{array}{c}\text { Designer's } \\
\text { fabrics }\end{array}$ & Intercept & $\begin{array}{c}\mathbf{X 1} \\
\text { Cloth } \\
\text { weight }\end{array}$ & $\begin{array}{c}\mathbf{X 2} \\
\text { Cloth } \\
\text { count }\end{array}$ & $\begin{array}{c}\text { X3 } \\
\text { Cloth } \\
\text { thickness }\end{array}$ & $\begin{array}{c}\mathbf{X} \text { 4 } \\
\text { Dummy } \\
\text { variable }\end{array}$ & $\mathbf{R}^{\mathbf{2}}$ & F-value \\
\hline 1 & Pin stripe & $\begin{array}{c}111.08^{* *} \\
(35.64)\end{array}$ & $\begin{array}{c}-0.15^{\mathrm{NS}} \\
(0.25)\end{array}$ & $\begin{array}{c}-0.13^{\mathrm{NS}} \\
(0.11)\end{array}$ & $\begin{array}{c}-0.09^{\mathrm{NS}} \\
(19.74)\end{array}$ & $\begin{array}{c}-30.00^{* *} \\
(2.82)\end{array}$ & $0.956^{* *}$ & 135.961 \\
\hline 2 & Medium stripe & $\begin{array}{c}143.85^{* *} \\
(30.54)\end{array}$ & $\begin{array}{c}-0.59^{* *} \\
(0.26)\end{array}$ & $\begin{array}{c}-0.09^{\mathrm{NS}} \\
(0.07)\end{array}$ & $\begin{array}{c}-8.18^{\mathrm{NS}} \\
(13.62)\end{array}$ & $\begin{array}{c}-27.43^{* *} \\
(1.87)\end{array}$ & $0.973^{* *}$ & 229.439 \\
\hline
\end{tabular}

Note: *Significant at 5 per cent level, ** Significant at 1 per cent level, NS- Non-significant

Figures in parenthesis indicate standard error 
In case of pin stripe fabric, the regression model explained 95.6 per cent of variation in the tensile strength due to variation in cloth parameters. The regression model was significant at 1 per cent. Cloth count, cloth weight and cloth thickness were having negative influence. However, these influences were statistically not significant. The tensile strength was found to decrease by 30.00 per cent from 111.08 per cent because of the treatment.

About 97 per cent of variation in tensile strength was found to explain by the variation in independent variables in the case of medium stripe fabrics. The F-value was very high indicating that the regression model was a good fit. The cloth weight was found to negatively and significantly condition the tensile strength. An increase of 1 GSM of cloth weight will decrease 0.59 per cent tensile strength. Cloth thickness and cloth count were found to influence tensile strength negatively. However, these influences were statistically not established. The tensile strength came down by 27.43 per cent due to the treatment.

\section{Conclusion}

Both WC and NCC yarns became finer on special finishing and there was slight increase in cloth count; considerable reduction in bending length; improvement in crease recovery angle and drapability of both the stripe fabrics was observed. Whereas, tensile strength and elongation were reduced; and no considerable change was observed in abrasion and pilling. Thus, the physical properties of both the khadi stripe fabrics have been improved by using safe and secured bio - finishing methods without using harmful chemicals which would affect the health of the consumers as well as destroy the ecosystem.

\section{References}

[1]. Booth, J. E., 1983, Principles of Textile Tesing. Edn. 6, CSB Publishers and Distributors, New Delhi

[2]. http://www.spectroresearchlabs.com/TextileTesting.aspx

[3]. Murthy, M.S.S., 2001, Study of coloured cotton. Deccan Herald, March, 13, p.3

[4]. Suman and Khambra, K., 2003, Effect of enzyme treatment on physical properties of denim. Synthetic Fibres, 32(4): 23-26.

[5]. Kurlageri, S. D., 2009, Impact of special finishes on mechanical and functional properties of organic cotton fabric. M.H.Sc. Thesis, Univ. Agric. Sci., Dharwad.

[6]. Raje, C. P., Gurjar, R.M. and Kawlekar, S. R., 2001, Finishing of cotton fabrics with cellulose enzyme. Indian Textile J., 111(6): $37-41$. 